\title{
Konbertasen rola tumorearen garapenean eta metastasian
}

\author{
Role of convertases in cancer development and metastasis \\ Ander MartinSan Sebastian ${ }^{1}$, Olatz Crende Arruabarrena ${ }^{2}$, Patricia García Gallastegi ${ }^{1}$ \\ ${ }^{1}$ UPV/EHU, Medikuntza eta Erizaintza Fakultateko Zelulen Biologia eta Histologia Saila \\ ${ }^{2}$ UPV/EHU, Farmazia Fakultateko Zelulen Biologia eta Histologia Saila \\ patricia.garcia@ehu.eus
}

\section{Laburpena}

Konbertasak proproteina inaktiboak heltzeaz arduratzen diren serin proteasak dira. Orain arte, zortzi konbertasa mota deskribatu dira: PC1, PC2, furina, PC4, PC5, PACE4, PC7, SKI-1 eta PCSK9. Haien funtzioak askotarikoak dira eta, neurri handi batean, ezinbestekoak. Horregatik, haren espresioan emandako edozein aldaketak homeostasian eragiten du eta patologiak sortzen ditu. Azpimarratzekoa da, bai PCSK9 proteasak hiperkolesterolemian baifurinak 2019-NCoV infekzioan duten garrantzia. Konbertasen inplikazioa batez ere garapen tumoralean aztertu da. Atxikitze-molekulen, metaloproteasen eta molekula proinflamatorioen heltzean duten parte-hartzea deskribatu da, horiek guztiak garapen tumoralean inplikatuta baitaude. Bestalde, zenbait konbertasaren inhibizioarekin tumoreen sorrera moteltzea lortzen dela frogatu da, prozesu horretan duen garrantzia egiaztatzen duelarik. Halaber, konbertasak mikroingurune tumoralean agertzen dira, zehazki Liver sinusoidal endotelial cells (LSEC) direlakoetan. Duela gutxi, mota zelular horretako PACE4 eta PCSK9 konbertasen espresioaren aldaketa deskribatu da, koloneko tumore-zelula metastasikoetatik eratorritako bitartekoekin kontaktuan jartzen denean. Behaketa horrek aukera ematen du konbertasek gibeleko prozesu metastasikoan duten inplikazioa aztertzeko eta proteina horiek diana terapeutiko berri bat izan daitezkeela pentsatzeko.

Gako-hitzak: Zelula endotelial hepatikoa, Konbertasak, Kolona, Mikroingurune tumorala

\section{Abstract}

Convertases are serine proteases responsible for the maturation of inactive proproteins. To date there are eight types of converters described PC1, PC2, Furine, PC4, PC5, PACE4, PC7, SKI-1 and PCSK9. The functions they perform are very diverse and, to a large extent, indispensable. Therefore, any alteration in their expression affects homeostasis and leads to pathologies. The involvement of PCSK9 in hypercholesterolemia and the involvement of Furine in 2019-NCoV infection should be noted. One of the pathologies in which the involvement of convertases has been most studied is the development of tumours. Their involvement in the maturation of adhesion molecules, metalloproteases and proinflammatory molecules, all of which are involved in tumour development, has been described. On the other hand, it has been observed that, when certain convertases are inhibited, the formation of tumours is slowed down, which shows their involvement in this process. Likewise, convertases are present in the tumour microenvironment, specifically in Liver sinusoidal endothelial cells (LSEC). Recently, the variation in the expression of PACE4 and PCSK9 convertases in this cell type when it comes into contact with media derived from metastatic colon tumour cells has been described. This observation opens the door to study the involvement of convertases in the hepatic metastasis process and suggests that these proteins could be a new therapeutic target.

$$
\text { Osagaiz - } 2021-5 \text {. bolumena - 1. zk.- } 69
$$


Bidalia: 352 - 21.01.14

Onartua: 2021.04.23

http://doi.org/10.26876/osagaiz.1.2021.353

\section{Konbertasak}

1967an intsulina proforma inaktibo batean sortzen zela ikusi zen, eta horrek itzulpen osteko aldaketak jasan behar izan zituela forma aktibora iristeko. Molekula hori prointsulina da, eta proproteinen konbertasen aurkikuntza ahalbidetu zuen, proteina inaktiboak heltzearen erantzule baitira (1). Haren aurkikuntza 60ko hamarkadakoa den arren, lehen konbertasa ez da 1990. urtera arte karakterizatuko, orduan hasi baitziren deskribatzen orain arte ezagutzen ditugun forma guztiak (2). Molekula horiek lotura peptidikoak hidrolizatzeaz arduratzen diren entzima serin proteasak dira, eta horietako bakoitza ebaki-puntu ezberdin baterako espezifikoa da. Orain arte 9 molekulaz osatuta dagoen familia da, eta PCSK1etik-9ra izenda daitezkeen arren, ezagunagoak dira nomenklatura honekin: PC1, PC2, furina, PC4, PC5, aminoazido basikoak zatitzeko entzima 4 (PACE4), PC7, azpilisina kexina 1 isoentzima (SKI-1; S1P izenez ere ezaguna) eta subtilisina kexina 9 proproteina konbertasa (PCSK9). Aipatzekoa da, halaber, konbertasen barruan azpifamilia bat dagoela, furina motako konbertasak izenez ezagutzen dena, konbertasa horren antzeko mozte-patroiak dituztelako. Hurrengo hauek dira konbertasa horiek: furina, PACE4, PC5 eta PC7 (3).

Konbertasak ehun ezberdinetan adierazten dira, salbuespenak PC1a eta PC2a sistema neuroendokrinoan eta PC4a barrabil eta obulutegien hozi-zeluletan baitaude. Zelularen barruko kokapenari dagokionez ere aldakorra da, PC1, 2 eta PC5en kasuan jariatze-besikuletan kokatzen dira, eta gainerakoak Trans Golgi eta endosometan daude. Knock-out saguetan proteina konbertasen galerak akats larriak eragin ditzake; hazkuntzan eta garapenean (PC1), kalteak timo guruinean (PC7), metabolismoan (PC2), ernalgarritasunean (PC4), eta PACE4 eta furina faltaren kasuan saguaren heriotza goiztiarra eragin dezake (1. irudian laburtua).

\begin{tabular}{|c|c|c|c|c|}
\hline $\begin{array}{c}\text { PROTEINA } \\
\text { KONBERTASA }\end{array}$ & SIZE & $\begin{array}{l}\text { EHUNEN } \\
\text { KOKAPENA }\end{array}$ & $\begin{array}{l}\text { LOKALIZAZIO } \\
\text { ZELULARRA }\end{array}$ & KO FENOTIPOA \\
\hline Furina & 794 & Zabala & TGN/Endosoma & Enbrioiaren heriotza 10.5 egunean \\
\hline PC7 & 785 & Zabala & TGN/Endosoma & Timo guruinaren akatsak \\
\hline PC5/6A* & 915 & Zabala & Jariatze besikulak & ED \\
\hline PC5/6B* & 1877 & Zabala & TGN/Endosoma & ED \\
\hline PACE 4 & 963 & Zabala & TGN/Endosoma & $\begin{array}{c}\text { Enbrioiaren heriotza } 15.5 \text { egunean, buruko eta NSZ } \\
\text { akatsak }\end{array}$ \\
\hline PC1/3 & 753 & Sistema Neuroendokrinoa & Jariatze-besikulak & $\begin{array}{l}\text { Saguan hazkuntza-akatsak GHRH eta POMC } \\
\text { prozesamenduan, hiperproinsulinemia }\end{array}$ \\
\hline PC2 & 638 & Sistema Neuroendokrinoa & Jariatze-besikulak & $\begin{array}{l}\text { Hipoguzemia, proinsulinemia, glukagon -urritasuna, } \\
\text { peptido opioideak prozesatzeko akatsa. }\end{array}$ \\
\hline PC 4 & 655 & Hozi zeluletan & ED & Ernalgarritasun osoa arretan, arina emeetan \\
\hline
\end{tabular}

1. irudia. Proteina konbertasen lokalizazioa ehunetan, zeluletan eta Knok-out (KO) saguen fenotipoa. ED: ez dago daturik (Thomas et al., 2002 erreferentziatik birmoldatuta). 


\section{Konbertasak eta haien funtzioa}

Konbertasen kokapen tisularra askotarikoa da. Horrela, furina, PC7 eta SKI-1 konbertasak nonahikoak dira, PC1a eta PC2a neuroendokrinoak, PC4a hozi-ehunetan dago, PC5a eta PACE4a giltzurrunetan edo hesteetan, beste organo batzuen artean, eta, azkenik, PCSK9a gibelean, hesteetan eta giltzurrunetan dago. Kokapenari gehitu behar zaio PC1, PC2, PC5, PACE4 eta PCSK9 konbertasak jariatuak direla, eta, beraz, plasman egon daitezkeela. Konbergentzia eta lokalizazio mota horiekin, logikoa da pentsatzea funtzio fisiologiko ugari dituztela. Adibidez, PC4ak, lerro germinalean dagoenez, ezinbesteko funtzioa betetzen du gizonezkoen ugalkortasunean, eta, beste alde batetik, PC2a ezinbestekoa da garapen-atzerapenak ez gauzatzeko saguetan (2). Furina, SKI-1 eta PC5 konbertasen kasuan, molekula horietarako knock-out banakoak egitean, enbrioien garapena ez da gauzatzen, eta horrek bizitzarako ezinbestekoak direla erakusten du. Era berean, nabarmentzekoa da konbertasa horiek guztiek maila homeostatikoan betetzen duten zeregina, proteina aktiboaren proportzioak eta proforma inaktiboa erregulatzearen bidez (4).

\section{Konbertasak patologian}

Molekula horiek funtzio ugari dituztela kontuan hartuta, logikoa da pentsatzea haien nahasmendua hainbat patologiatan inplikatuta dagoela. Horrela, PCSK9ak hiperkolesterolemian eta eratorritako arteriosklerosian duen inplikazioa deskribatu da. Horren arrazoia da PCSK9agai dela gibelean dagoen LDL kolesterolaren hartzailea hidrolizatzeko eta, hartzailearenmailak murriztean, zelula hepatikoek ezin dutela LDL kolesterola barneratu, eta, horrela, kolesterolaren maila plasmatikoa handitu egiten da. Izan ere, hainbestekoa da PCSK9aren inplikazioa gaixotasun honetan, molekula horren aurkako antigorputzak garatzen ari baitira LDL kolesterol plasmatikoaren mailak murrizten saiatzeko (5).

Bestalde, konbertasek beste gaixotasun mota batzuetan duten inplikazioa ere deskribatu da. Adibidez, furinak berebiziko garrantzia du ebola edo 2019-nCoV birusak eragindako infekzio biralean. 2019-NCoV birusak mundu-mailan eragin handia izan duenez, haren infekzio-mekanismoaren azterketa lehentasunezkoa izaten ari da. Horrela, infekzioa ahalbidetzen duen eta birusaren mintzean adierazten den proteina batek furinak ezagutzen duen ebaketa-puntu bat duela frogatu da. Horrek erakusten du furina inplikatuta egon daitekeela proteina horren heltze-prozesuan, birusaren infekziomekanismoa bultzatuz (6). Era berean, furinak Alzheimerra eragiten duten plaka amiloideoen eraketan parte hartzen du. Baina, batez ere, konbertasek tumore-garapenean duten eginkizuna aztertzen ari dira, erakutsi baita hainbat rol betetzen dituztela tumore-garapenaren eta kokapenaren arabera (1).

\section{Konbertasak minbizian}

Konbertasek tumorearen gaitasun inbaditzailean eta tumore primarioaren garapenean inplikatuta dauden hainbat molekulari heltzen diete, adibidez, metaloproteinasei eta lotura-proteinak diren integrinei eta kadherinei. Beraz, garapen tumoralaren eta konbertasen artean erlazio zuzena dago. Hala, tumore desberdinetako konbertasa-mailetan aldaketak daude, adibidez, buruko, lepoko eta azaleko tumoreetan PACE4aren gehiegizko espresioa (7).

Behaketa horien ondorioz, azterketa molekularrak egin behar izan dira, konbertasen espresiomailetan aldaketa horiek zergatik gertatzen diren ulertzen saiatzeko. Horrela, frogatu da furina eta PACE4 konbertasak 3 estromelisinaren (MMP-11 edo Str-3) heltzean inplikatuta daudela.Molekula horien forma heldu eta aktiboa tumoreen inbasioan inplikatuta dagoen metaloproteasa (MMP) da. Halaber, mintzaren metaloproteasek (MT-MMP), hazkuntza-faktoreek eta kadherina bezalako atxikitze-molekulek aminoazidoen antzeko ereduak dituzte. Beraz, badirudi furinak eta PACE4ak azken molekula horiek aktiba ditzaketela (8). Ikusi da, halaber, furina eta PC5a MT1-MMPei eta PACE4a MT2-MMPei heltzeko gai direla. Ezaugarri hori bereziki interesgarria da tumorearen 
garapenean; izan ere, metaloproteasak gai dira zelulaz kanpoko matrizearen osagaiak degradatzeko eta, horrela, tumorea garatzeko eta barreiatzeko (9).

Prozesu tumoraleko konbertasen beste alde aztertuenetako bat atxikitze-molekulei heltzeko gaitasuna da. Lehenik eta behin, furinak eta PC5ak integrinen alfa azpiunitateen heldutasunean duten inplikazioa erakutsi da. Era berean, PC7ak eta PC5ak kadherinen proE-kadherinei heltzean jarduten dute, E-kadherinak sortzea ahalbidetuz, zelulen arteko loturetan oso ugariak diren atxikitzemolekulak, hain zuzen (10). Furina ICAM-1 eta VCAM-1atxikitze-molekulenaktibazio-prozesuan ere inplikatuta dago. Konbertasen ezaugarri hori funtsezkoa da tumorearen garapenean; izan ere, metastasia gertatzen denez, tumore-zelulek migratu egiten dute, eta nitxo aktibatura iritsi behar dute, non atxikitzeko molekulak ugariak diren, hartara, atxikitzeko eta tumore metastasikoa eratzen hasteko (11).

Minbiziaren eta hantura-prozesuaren arteko erlazioa oso ondo aztertu da, eta horrek agerian uzten du konbertasek minbizian duten papera ikertzeko interesa. Ikusi da furinak eta PACE4ak funtsezko eginkizuna dutela prozesu tumoralean inplikatuta dauden molekula proinflamatorioen heltzean, hala nola TGF-1. Halaber, furinaren familiako konbertasek berebiziko garrantzia dute hanturak eragindako angiogenesian adierazten diren faktoreei heltzen. Faktore horiek VEGF, PDGF eta IGF dira (12). Nabarmentzekoa da furina gai dela IGF-1 hartzailea ontzeko, metastasian erabakigarria den hazkunde-faktorea (11). Hala, Siegfriedek eta laguntzaileek 2020an egindako ikerketan, furinaren familiaren konbertasak inhibitu ziren zelula endotelialen kultibo batean, eta koloneko zelula metastasikoak gehitu ziren, azken horien atxikimendua aztertzeko. Ikusi zenez, furinaren familiako konbertasak inhibitzean, zelula metastasikoen atxikitze-mailak nabarmenki murrizten dira. Beraz, konbertasa horiek eragina dute endotelioaren aktibazioan, hantura-bitartekarien heltzearen bidez. Horretaz gain, tumorearen garapenean inplikatuta ere badaude, IGF-1aren heltzeari esker. Modu horretan, TNF-alfaren pilaketa errazten da, garapen metastasikorako beharrezkoa den seinalizaziobidea ahalbidetuz (12).

Konbertasen hantura-prozesuan eta garapen tumoralean duten zereginarekin bat etorriz, immunoterapia bidezko minbiziaren tratamenduetan eginkizunik duten aztertu da, zehazki PD1aren aurkako antigorputzetan. Tratamendu horietan, T linfozito ahitu ugari detektatzen dira epe luzera, ugaltzeko eta zitotoxikotasun txikiagoa dutenak. Zelula horiek PD-1 hartzaile maila eta FAS hartzaile bidezko apoptosi-maila handiagoak dituzte. Furina eta PC7 konbertasak inhibituz, bi fenomeno horiek leheneratzea lortu da, T linfozito ahituen kopurua murriztuz. Horri esker, minbizi errepikatuak tratatzeko konbertasen inhibitzaileak erabiltzeko aukera dago; izan ere, immunoterapiarekin tratatu dira dagoeneko, $\mathrm{T}$ linfozito ahituak berraktibatzeko (13).

Era berean, garrantzi handikoa da garapen tumoralean PCSK9ak LDL kolesterolaren hartzailearen mailak erregulatzeko duen zeregina. Konbertasa hori gibelean adierazten da batez ere, eta gibeleko metastasian duen eragina aztertu da. Modu horretan, PCSK9aespresatzen ez duten hepatozito primarioek TNF-alfa mailak baxu mantenduz kolesterol intrazelularraren maila erregulatzen dutenez, gibelaren estroma eta apoptosiaren zelula metastasikoak babesten dituztela ikusi da. Maila molekularreko behaketa horiek PCSK9a adierazten ez duten saguetan egiaztatu dira.Horrela, ikusi da nola PCSK9aespresatzen ez duten saguak sagu basatiekin alderatuta melanoma-zelula metastasikoak injektatzean baino metastasi-maila nabarmen baxuagoa duten(14).

Azken fenomeno hori, gibeleko metastasia, aztertuenetako bat da. Bereziki interesgarria da koloneko kartzinomaren gibeleko metastasia aztertzea; izan ere, kolonekoa lehen mailako tumore ohikoenetako bat da, eta gibela metastatizatzeko joera du, metastasi mota hori ohikoenetako bat bihurtuz. Prozesu horretan, konbertasek ere funtsezko zeregina dute. Azterlan horiek egin dira, batetik, furinaren familiaren konbertasekin, hau da, furina, PACE4, PC5 eta PC7arekin, eta, bestetik, PC1 eta PC2arekin. Furinaren familiako konbertasak aztertzeko, hiru inhibitzaile erabili dira: alfaPDXa, Spn4A eta ppFurina. PC1 eta PC2aren kasuan, bi konbertasa horiek metastasian duten forma aktiboaren eta inaktiboaren mailak aztertu ziren. 
Alfa-PDX inhibitzailearekin egindako azterlanaren kasuan, egiaztatu zen metastasia gertatu aurretik endotelioa aktibatu behar dela. Endotelioa aktibatzeko, IL-1, IL-6 eta TNF-alfa jariatzen dira, baita VEGF, IGF-1, PDGH eta endotelina ere; horiek guztiak, neurri handi batean, konbertasen bidez aktibatzen dira. Interes berezikoa da IGF-1a, eta haren hartzailea furinak erregulatzen du, lehen adierazi bezala. Hazkunde-faktore hau apoptosia blokeatzeko gai da, horrela tumorearen garapena bultzatzen du eta E-selektina eta TNF-alfa mailak aldatzen ditu. Horrela, alfa-PDX inhibitzailea gehitzean, endotelioari atxikitzeko zelula metastasikoetan beharrezkoa den E-selektinaren espresioa jaitsi egin zela ikusi zen, baita IL-1 eta TNF-alfa mailak eta tumoreen baskularizazioa murriztu egin zirela ere. Modu horretan, ondoriozta daiteke furinaren familiako konbertasak endotelioaren aktibazioan inplikatuta daudela (15).

Spn4A inhibitzailearen efektua furinaren familiako konbertasen inhibizioan alfa-PDXarena baino 50 aldiz handiagoa da. Horrela, Spn4A erabiliz, koloneko tumore-zeluletan proPDGF-A eta prolGF-1R direlakoen prozesamendua blokeatu zen. Era berean, furinaren inhibizioak MT1-MMParen aktibazioaren murrizketa eragin zuen, eta, bestalde, PACE4, PC5 eta PC7aren inhibizioa gertatu zen cPDGF-A eta VEGF-C substratuen blokeoaren ondorioz. Izan ere, azken bi horiek funtsezko faktoreak dira angiogenesian eta tumore-progresioan (16). PpFurina inhibitzaile gisa erabiltzeak PDGFaren eta IGF-1Raren produkzioaren beherakada eragin zuen, eta koloneko gibeleko metastasiaren mailak ere behera egin zuen (15). 3 azterlan horiek erakusten dute furinaren familiako konbertasek funtsezko eginkizuna dutela koloneko gibeleko metastasian, eta fenomeno hori prebenitzeko jomuga terapeutiko gisa funtziona dezaketela.

Garrantzitsua da aipatzea furinaren familiaren konbertasak prozesu horretan inplikatzeaz gain, PC1ak eta PC2ak duten zeregina ere aztertu dela. Konbertasa horiek erretikulu endoplasmatikoan proforma inaktibo eran sortzen eta Golgi aparatuan heltzen dira. Heltzeko, PC2ak $7 \mathrm{~b} 2$ proteina behar du, chaperonen familiako proteina bat. Gibeleko metastasian PC1 eta PC2 aktiboen gainespresioa detektatzen da. Era berean, 7b2-ko gainespresioaikusten da, eta horrek azal lezake PC2 aktiboaren igoera. Koloneko tumore primarioetan ere hori gertatzen denez, iradoki daiteke konbertasa aktiboak gainespresatuta dituzten zelulek migratzeko eta gibeleko metastasia sortzeko joera nabariagoa izango dutela (17).

\section{Konbertasen rola mikroingurune tumoralean}

Tumore-zelulen konbertasek betetzen duten papera asko aztertzen ari den arren, oraindik asko dago jakiteko entzima horiek tumorearen mikroingurunean duten eginkizunari dagokionez. Zehazki, koloneko minbiziaren gibeleko metastasian sinusoide hepatikoa osatzen duten zelula endotelialen Liver Sinusoidal Entothelial Cell (LSEC) izenez ere ezagutzen direnak- konbertasak aztertzea interesgarria izan daiteke. Zelula mota horrek funtzio fisiologiko ugari ditu, hala nola odoleko makromolekulak edo partikula txikiak ezabatzea edo haien rol immunologikoa, IGG eta lipopolisakaridoa kenduz. Baina gibeleko metastasien garapenean ere funtsezko eginkizuna du (18).

LSECek metastasian dituzten rolen artean, tumore-zelulak lotzea ahalbidetzen duten atxikitzemolekulak adierazteko gaitasuna nabarmentzen da. Horrela, seinale inflamatorioak endoteliora iristean, zelula horiek E-selektina, VCAM-1 eta ICAM-1 atxikitze-molekulak adierazten hasten dira,eta horrela tumore-zelulei atxikitzeko bide ematen die. E-selektina diapedesi-prozesuarekin eta tumorezelulen migrazio transendotelialarekin erlazionatu da (19). Bestalde, ICAM-1ek kartzinoma kolorrektalaren (KKR) potentzial metastatikoarekin erlazio handia duela erakutsi da. In vitro ereduen bidez frogatu da KKRaren zelula metastasikoen LFA-1aren eta zelula endotelialen ICAM-1arenarteko elkarrekintzakIL-1 $\beta$, IL-6, TNF-alfa eta PGE2 mailetan igoerak eragiten dituelaeta parametro horiek in vivo metastasietan aldatuta daudela. VEGF, MMP-1 eta MMP-9 mailak ere aldatzen direla ikusi da, eta horrek lotura horren eta angiogenesiaren arteko erlazioa adierazten du (20). Odol-hodiak sortzea funtsezko fenomenoetako bat da garapen metastasikoan. LSECak dira tumorea irrigatu eta hazkunde metastasikoa ahalbidetzen duten hodi horiek eratzeaz arduratzen direnak (21). Zelula mota hori, 
gainera, MIF (Macrophage Migration Inhibitory Factor), KKR zelulak gibelera erakartzen dituen molekula kimiotaktikoa, jariatzeko gai da.

Horrek erakusten du LSECek zuzeneko inplikazioa dutela gibeleko metastasien eraketan. Era berean, aipatutako fenomeno guztiak - atxikitzeko molekulen espresioa, angiogenesia, molekulen jariatzeakonbertasen eraginez bideratzen dira. Horri esker pentsa daiteke LSECek konbertasak espresatzen dituztela, substratuak prozesatzeko gai direnak eta prozesu metastasikoan zuzeneko inplikazioa dutenak.

Horrela, konbertasak aztertzea oso lagungarria izan daiteke gibeleko metastasiaren garapena eta funtzionamendua ulertzeko. Izan ere, duela gutxi, gure taldeak erakutsi du, koloneko tumore-zelula metastasikoek jariatutako konposatuak zelula endotelialekin harremanetan jartzean, aldaketak gertatzen direla konbertasen mRNA mailetan LSECetan (argitaratzeke dagoen azterketa). Azterketa horiek guztiek garrantzi handia dute konbertasen aldetik, baina betiere tumorearen ikuspegitik; eremu handia geratuko litzateke gaixotasunaren garapenean mikroingurune tumoraleko zeluletako konbertasen kasuan esploratzeko, eta zehatzago esanda, LSEC direlakoetan.

Bestalde, azken urteotan frogatu da exosomak, hau da, zelulen arteko komunikazioa ahalbidetzen duten mikrobesikula estrazelularrak, koloneko kartzinomaren gibeleko metastasian inplikatuta daudela. Exosoma horiek KKRaren zelulek jariatuko lituzkete, eta, horrela, endotelioa aktibatzea lortuko litzateke, eta arestian aipatutako fenomenoak gertatzea, hala nola LSECek atxikitzeko molekulen espresioa (22). Baina, fenomeno hau ez da oso sakonki aztertu, eta kontrako norabidean ematea ere posible da, hau da, zelula endotelialak exosomak jariatu eta horiek tumore-zelulen gain eragitea, edo forma parakrinoan ondoko zelula endotelialetan.

Horrela, pentsa daiteke exosoma horien edukiak tumore-zelulen konbertasen aktibazioan ondorioak izango dituela, eragin prometastatiko bat izanik, koloneko minbizi-zelulen gibeleko metastasia bultzatuz.

\section{Eztabaida}

Azaldu den bezala,badirudi proteina konbertasak minbizia tratatzeko balizko diana terapeutikoa direla; izan ere, inhibituz gero, angiogenesi-prozesua geldiaraz lezake, edo minbiziaren agresibitatea murriztu. Baina horretaz ziur egon ahal izateko, arlo honetako ikerketekin jarraitzea beharrezkoa da; funtzio ugari betetzen dituztenez, erabateko inhibizioak edo inhibizio partzialaksor ditzakeen ondorio guztiak ezagutu arte, horietako batzuk kaltegarriak izan daitezke eta.Gainera, zenbait ikerketak erakusten dutekonbertasa batzuk gaiespresatzeak tumorearen erregresioan lagundu dezakeela. Azkenik, aurretik adierazi den bezala, gibeleko zelula sinusoidalen konbertasekin, beste ikerketa-ildo bat ireki da, metastasi hepatikoa duen koloneko minbiziarentzako tratamendu zehatzagoak garatzea ekar dezakeena. Horiek nabarmen murriztu ditzakete egungo tratamenduek eragindako alboondorioak.

\section{Erreferentzia bibliografikoak}

1. Artenstein AW, \& Opal SM. Proprotein convertases in health and disease. New England Journal of Medicine.2011;365:2507-2518.

2. Seidah NG. The proprotein convertases, 20 years later. Methods in Moleculas Biology. 2011;768:23-57.

3. Seidah NG \& Prat A. The biology and therapeutic targeting of the proprotein convertases. Nature Reviews Drug Discovery. 2012;11(5):367-383. 
4. Seidah NG, Mayer G, Zaid A, Rousselet E, Nassoury N, Poirier S, Essalmani R, Prat A. The activation and physiological functions of the proprotein convertases. International Journal of Biochemistry and Cell Biology. 2008;40(6-7):1111-1125.

5. Seidah NG. Proprotein Convertase Subtilisin Kexin 9 (PCSK9) Inhibitors in the Treatment of Hypercholesterolemia and other Pathologies. Current Pharmaceutical Design. 2013;19(17):3161-3172.

6. Coutard B, Valle C, Lamballerie XDe, Canard B, Seidah NG,Decroly E. The spike glycoprotein of the new coronavirus 2019-nCoV contains a furinlike cleavage site absent in CoV of the same clade. Antiviral Research. 2020;176(4):1-4.

7. Khatib AM, Siegfried G, Chrétien M, Metrakos $P$, Seidah NG. Proprotein convertases in tumor progression and malignancy: Novel targets in cancer therapy. American Journal of Pathology. 2002;160(6): 1921-1935.

8. Bassi DE, Mahloogi H,Klein-Szanto AJP. The proprotein convertases furin and PACE4 play a significant role in tumor progression. Molecular Carcinogenesis. 2000;28(2):63-69.

9. Bassi DE, Fu J, De Cicco RL,Klein-Szanto AJP. Proprotein convertases: "Master switches" in the regulation of tumor growth and progression. Molecular Carcinogenesis. 2005;44(3):151-161.

10. Posthaus $H$, Dubois $C M$, Müller E. Novel insights into cadherin processing by subtilisin-like convertases. FEBS Letters. 2003;536(1-3):203-208.

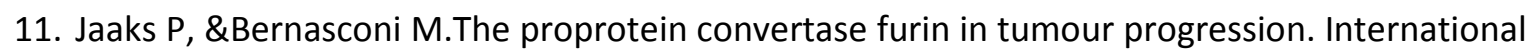
Journal of Cancer. 2017;141(4):654-663.

12. Siegfried G, Descarpentrie J, Evrard S, Khatib AM. Proprotein convertases: Key players in inflammation-related malignancies and metastasis. In Cancer Letters. 2020;473:50-61.

13. Tome M, Pappalardo A, Soulet F, Lopez JJ, Olaizola J, Leger Y, Dubreuil M, Mouchard A, Fessart D, Delom F, Pitard V, Bechade D, Fonck M, Rosado JA, Ghiringhelli F, DechanetMerville J, Soubeyran I, Siegfried G, Evrard S, Khatib AM. Inactivation of proprotein convertases in $\mathrm{T}$ cells inhibits PD-1 expression and creates a favorable immune microenvironment in colorectal cancer.Cancer Research. 2019;79(19): 5008-5021.

14. Sun X, Essalmani R, Day R, Khatib AM, Seidah NG, Prat A. Proprotein convertase subtilisin/kexin type 9 deficiency reduces melanoma metastasis in liver. Neoplasia (United States). 2012;14(12):1122-1131.

15. Scamuffa N, Sfaxi F, Ma J, Lalou C, Seidah N, Calvo F, Khatib AM. Prodomain of the proprotein convertase subtilisin/kexin Furin (ppfurin) protects from tumor progression and metastasis. Carcinogenesis. 2014;35(3):528-536.

16. Sfaxi F, Scamuffa N, Lalou C, Ma J, Metrakos P, Siegfried G, Ragg H, Bikfalvi A, Calvo F, Khatib AM.Repression of liver colorectal metastasis by the serpin Spn4A a naturally occurring inhibitor of the constitutive secretory proprotein convertases.Oncotarget. 2014;5(12):41954210.

17. Tzimas GN, Chevet E, Jenna S, Nguyên DT, Khatib AM, Marcus V, Zhang Y, Chrétien M, Seidah $\mathrm{N}$, Metrakos $\mathrm{P}$. Abnormal expression and processing of the proprotein convertases PC1 and PC2 in human colorectal liver metastases. BMC Cancer. 2005;5:1-11.

18. DeLeve LD, \& Maretti-Mira AC. Liver Sinusoidal Endothelial Cell: An Update. Seminars in Liver Disease. 2017;37(4):377-387.

19. Brodt P. Role of the microenvironment in liver metastasis: From pre- to prometastatic niches. Clinical Cancer Research. 2016;22(24):5971-5982.

20. Benedicto A, Herrero A, Romayor I, Marquez J, Smedsrød B, Olaso E, Arteta B. Liver sinusoidal endothelial cell ICAM-1 mediated tumor/endothelial crosstalk drives the development of 
Ander Martin San Sebastian, Olatz Crende Arruabarrena, Patricia García Gallastegi

liver metastasis by initiating inflammatory and angiogenic

responses. Scientific. Reports. 2019;9(1):1-12.

21. Clark AM, Ma B, Taylor DL, Griffith L,Wells A. Liver metastases: Microenvironments and exvivo models. Experimental Biology and Medicine. 2016;241(15):1639-1652.

22. Ruiz-López L, Blancas I, Garrido JM, Mut-Salud N, Moya-Jódar M, Osuna A,Rodríguez-Serrano F. The role of exosomes on colorectal cancer: A review. Journal of Gastroenterology and Hepatology (Australia). 2018;33(4):792-799.

23. Thomas G. Furin at the cutting edge: from protein traffic to embryogenesis and disease. Nat. Rev. Mol. Cell Biol. 2002;3:753-766. 